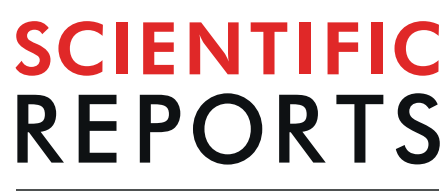

natureresearch

\title{
Integrin $\alpha 11$ cytoplasmic tail is required for FAK activation to initiate 3D cell invasion and ERK- mediated cell proliferation
}

\author{
Pugazendhi Erusappan ${ }^{1,2}$, Jahedul Alam ${ }^{1}$, Ning Lu ${ }^{1}$, Cédric Zeltz ${ }^{1,3}$ \& Donald Gullberg ${ }^{1 *}$
}

Integrin $\alpha 11 \beta 1$ is a collagen-binding integrin, which is receiving increasing attention in the context of wound healing and fibrosis. Although $\alpha 11 \beta 1$ integrin displays similar collagen specificity to $\alpha 2 \beta 1$ integrin, both integrins have distinct in vivo functions. In this context, the contribution of $\alpha 11$ subunit cytoplasmic tail interactions to diverse molecular signals and biological functions is largely unknown. In the current study, we have deleted the $\alpha 11$ cytoplasmic tail and studied the effect of this deletion on $\alpha 11$ integrin function. Compared to wild-type cells, C2C12 cells expressing tail-less $\alpha 11$ attached normally to collagen I, but formed fewer focal contacts. $\alpha 11$-tail-less cells furthermore displayed a reduced capacity to invade and reorganize a 3D collagen matrix and to proliferate. Analysis of cell signaling showed that FAK and ERK phosphorylation was reduced in cells expressing tail-less $\alpha 11$. Inhibition of ERK and FAK activation decreased $\alpha 11$-mediated cell proliferation, whereas $\alpha 11$ mediated cell invasion was FAK-dependent and occurred independently of ERK signaling. In summary, our data demonstrate that the integrin $\alpha 11$ cytoplasmic tail plays a central role in $\alpha 11$ integrin-specific functions, including FAK-dependent ERK activation to promote cell proliferation.

Integrins are heterodimeric cell surface receptors composed of non-covalently associated $\alpha$ and $\beta$ subunits, which act as cell surface links to the extracellular matrix (ECM) and to other cells in dynamic cell-cell linkages $^{1}$. Integrin subunits are composed of different domains with different functions. The extracellular domain of collagen-binding $\alpha$ integrin chains contain an inserted $\alpha$-I domain, which is responsible for collagen binding without direct involvement of the $\beta$ subunit. Whereas different integrin $\beta$ chains display conserved regions including their cytoplasmic tail, the cytoplasmic tails of integrin $\alpha$ chains show little sequence similarity except for the very proximal membrane sequence GFFXR ${ }^{2}$. It is interesting in this context to note that $\alpha 11$ integrin lacks the conserved GFFXR sequence, but instead the $\alpha 11$-tail contains the GFFRS sequence ${ }^{3}$. A number of proteins have been found to bind to the conserved GFFXR sequence without displaying specificity for any particular $\alpha$ chain $^{2}$. The conserved GFFXR site has been demonstrated to bind, for example, SHARPIN ${ }^{4}$, which keeps integrin in an inactive conformation. Other proteins reported to bind to the conserved membrane proximal region include Rab21, Nischarin and PP2A ${ }^{2}$. Deletion of GFFXR or mutation of Arginine in the GFFXR sequence render integrins constitutively active, suggested to occur as a result of breakage of a salt linkage between $\alpha$ chains and $\beta$ chain $^{5}$. If the deletion occurs beyond the GFFXR sequence, effects vary depending on the nature of the $\alpha$ chain and the cellular background ${ }^{6}$.

Molecular interactions of the integrin cytoplasmic tails can both regulate inside-out and outside-in signaling as well as strengthening the actin linkages ${ }^{2,7}$. The NPXY motifs located in the $\beta$ subunits are important binding sites for talins and kindlins, both taking part in integrin inside-out signaling ${ }^{8,9}$. These important interactions in turn are regulated through binding of other proteins such as Dok1 and ICAP-1, to the same integrin $\beta$ chain NPXY motifs. In addition, phosphorylation of the proximal NPXY motif appears to be a molecular switch to regulate tensin binding and localization of $\alpha 5 \beta 1$ to fibrillar adhesions ${ }^{10}$. More recent data have demonstrated that integrin $\alpha$ chains contribute to filamin A-, talin-, and kindlin-binding to the integrin $\beta$ subunits ${ }^{11-14}$. Data are thus

${ }^{1}$ Department of Biomedicine and Center of Cancer Biomarkers, University of Bergen, Jonas Lies vei 91, N-5009, Bergen, Norway. ${ }^{2}$ Institute for Experimental Medical Research, Oslo University Hospital and University of Oslo, Kirkeveien 166, 0450, Oslo, Norway. ${ }^{3}$ Princess Margaret Cancer Center, University Health Network, 101 College Street, Toronto, ON, M5G 1L7, Canada. *email: donald.gullberg@uib.no 
accumulating with indications that integrin $\alpha$ cytoplasmic tails take an active part in interactions of importance for integrin heterodimer function.

Careful analyses of mice lacking individual collagen-binding integrins show that the collagen-binding integrin receptors are dispensable for normal development, but suggest important roles for these receptors in tissue remodeling events occurring in wound healing, fibrosis and tumor-stroma interactions ${ }^{15}$. $\alpha 11 \beta 1$ integrin is a collagen receptor, which is the latest identified member of the integrin family ${ }^{3,16,17}$. Although $\alpha 11$ shows an overall sequence homology to other collagen-binding integrin $\alpha$ chains of the $\beta 1$ subfamily and also displays similar collagen specificity as $\alpha 2 \beta 1$ integrin, $\alpha 11 \beta 1$ integrin in vivo has functions distinct from the other collagen-binding integrins ${ }^{18-22}$. This suggests that $\alpha 11$ cytoplasmic tail may regulate $\alpha 11$ functions. The role of cytoplasmic tails of collagen-binding integrins has been studied extensively in the 1990s by the group of Hemler et al. Deletion of the $\alpha 2$ integrin cytoplasmic tail in K562 and RD cells (both requiring integrin activation) demonstrated that the $\alpha 2$ -tail-less integrin showed reduced adhesive activity on collagen I, in a manner suggesting an activation defect ${ }^{23}$. In chimeric experiments where again the $\alpha 2$ cytoplasmic tail was replaced with the tail of other integrins, it was demonstrated that chimeric $\alpha 2$ integrins with $\alpha 5$-tail $(\mathrm{X} \alpha 2 \mathrm{C} \alpha 5)$ could mediate collagen gel contraction, whereas chimeric $\mathrm{X} \alpha 2 \mathrm{C} \alpha 4$ failed to mediate contraction, but instead promoted cell migration ${ }^{24}$. Already at this time it was speculated that " $\alpha$ subunit cytoplasmic domains, probably acting in concert with their associated $\beta$ subunit, also have important but distinct roles and perhaps eventually will be shown to interact with distinct set of intracellular proteins" ${ }^{24}$. More recent data, using more sensitive assays, analyzing chimeras of all $12 \alpha$ chains of the $\beta 1$ integrin subfamily confirm that cytoplasmic tails of integrin $\alpha$-chains do affect integrin inside-out activation, but that this varies greatly between different integrin $\alpha$ chains ${ }^{25}$. Deletion experiments are thus not easy to interpret since one also has to consider possible modulatory effects on integrin $\alpha / \beta$ chain interactions.

In the current study, we have deleted the $\alpha 11$ cytoplasmic tail and studied the effect of this deletion on $\alpha 11$ integrin function. Our data show that the integrin $\alpha 11$ cytoplasmic tail is dispensable for cell attachment but is essential for focal adhesion formation, ERK-dependent cell proliferation, cell migration and reorganization of 3D collagen matrices.

\section{Results}

Generation and expression of a human integrin $\alpha 11$-tail-less variant. In order to identify the role of the $\alpha 11$ cytoplasmic tail, a mutant variant $\left(_{\mathrm{Hu}} \mathrm{\alpha} 11-1171\right)$ with a deletion of the terminal 17 amino acids in the cytoplasmic tail of human integrin $\alpha 11\left(_{\mathrm{Hu}} \alpha 11\right)$ was generated. Since the antibodies used to detect human $\alpha 11$ react with the cytoplasmic tail ${ }^{26}$, we have EGFP-tagged the integrin carboxy terminus using a 10 amino acid linker to avoid interference of the EGFP tag. Horwitz et al. pioneered this strategy for integrin $\alpha 5$ and the resultant tagged $\alpha 5$ integrin was characterized in detail without any evidence of artifacts due to the EGFP $\operatorname{tag}^{27}$. Full-length $(\mathrm{Hu} \alpha 11-W T)$ and tail-less $\left(_{\mathrm{Hu}} \alpha 11-1171\right)_{\mathrm{Hu}} \alpha 11$ variants were tagged with enhanced green fluorescence protein (EGFP) and expressed in $\mathrm{C} 2 \mathrm{C} 12$ mouse myoblasts, which do not express any collagen-binding integrins ${ }^{28}$ (Fig. 1A). Based on EGFP intensity, the transfected cells were sorted by flow cytometry with uniform gating to obtain similar expression levels of EGFP. The expression of comparable levels of ${ }_{\mathrm{Hu}} \alpha 11$-EGFP in the total protein lysates was confirmed by immunoblotting, either with an anti- ${ }_{\mathrm{Hu}} \mathrm{\alpha} 11$ polyclonal antibody or with an anti-EGFP antibody (Fig. 1B). Comparable expression levels of ${ }_{\mathrm{Hu}} \alpha 11$-EGFP at the cell surface were also confirmed, using mock transfected cells (Mock, empty GFP vector) as a negative control (Fig. 1C).

Integrin $\alpha 11$ cytoplasmic tail is dispensable for cell adhesion but mediates focal adhesion formation, collagen reorganization, cell migration and cell proliferation. To examine the role of integrin $\alpha 11$ cytoplasmic tail in cell adhesion, ${ }_{\mathrm{Hu}} \alpha 11-\mathrm{WT}$ and ${ }_{\mathrm{Hu}} \alpha 11-1171$ cells were allowed to attach to collagen I or fibronectin using BSA coated wells as negative control. Mock transfected cells did not adhere to collagen, whereas $_{\mathrm{Hu}} \alpha 11-\mathrm{WT}$ and $\mathrm{Hu}_{\mathrm{Hu}} \alpha 11-1171$ cells adhered equally well to collagen I and fibronectin. This suggests that the deletion of 17 amino acids in the cytoplasmic tail of ${ }_{\mathrm{Hu}} \alpha 11$ had no apparent negative influence on integrin activation or cell adhesion to collagen I (Fig. 2A). However, ${ }_{\mathrm{Hu}} \alpha 11-1171$ cells displayed fewer focal adhesions after 2 hours, with a reduction of $50 \%$ in the total area of focal adhesions (Fig. 2C) and 35\% reduction in cell spreading (Supplementary Fig. 2). This indicates that cytoplasmic tail of integrin $\alpha 11$ is involved in mediating cell adhesion signaling. To confirm this hypothesis, we assessed the ability of $\mathrm{Hu}_{\mathrm{Hu}} \mathrm{\alpha 1-1171}$ cells in mediating: collagen gel reorganization, cell migration and proliferation.

When cells were allowed to attach on collagen I for 24 hours in low serum conditions, ${ }_{\mathrm{Hu}} \alpha 11-1171$ cells displayed a significant reduction in cell proliferation compared to ${ }_{\mathrm{Hu}} \mathrm{\alpha} 11-\mathrm{WT}$ cells, but not on fibronectin, suggesting that the $\alpha 11$ cytoplasmic tail-mediated signaling is involved in the regulation of cell proliferation (Fig. 2B). We further examined the ability of these cells to contract $3 \mathrm{D}$ collagen I lattices, a process previously shown to be $\alpha 2 \beta 1$ - and $\alpha 11 \beta 1$ - mediated ${ }^{18,28,29}$. Sixteen hours after the contraction was initiated, the ${ }_{\mathrm{Hu}} \alpha 11-1171$ cells displayed 50\% reduction in collagen contraction compared to ${ }_{\mathrm{Hu}} \alpha 11-\mathrm{WT}$ cells (Fig. 2D).

We also investigated the role of the $\alpha 11$ cytoplasmic tail in cell migration using a spheroid migration model in a 3D collagen matrix. The radial cell density profile of the spheroid was analyzed from the center of the spheroid to quantify migrated cells in relation to their distance of migration. ${ }_{\mathrm{Hu}} \mathrm{\alpha} 11$-WT cells migrated out $50 \%$ more than $\mathrm{Hu} \alpha 11-1171$ and mock transfected cells, beyond $400 \mu \mathrm{m}$ from the center of the spheroid (Fig. 2E). Interestingly, the size of the spheroid core for the ${ }_{\mathrm{Hu}} \mathrm{\alpha} 11-\mathrm{WT}$ cells was smaller than that observed for spheroids formed from the $\mathrm{Hu}_{\mathrm{Hu}} \mathrm{\alpha} 1 \mathrm{-1171}$ and Mock cells. These results indicate that the $\alpha 11$ cytoplasmic tail is indeed essential to mediate cell proliferation, collagen reorganization and cell migration.

Integrin $\alpha 11$ cytoplasmic tail contributes to FAK and ERK activation. Localization of focal adhesion kinase (FAK) in focal adhesions and its autophosphorylation at Tyrosine residue $397\left(\mathrm{FAK}^{\mathrm{Y} 397}\right)$ is a primary event in integrin signaling leading to cell migration and proliferation ${ }^{30-33}$. Analysis of FAK $^{\mathrm{Y} 397}$ activation 
A

\begin{tabular}{|c|c|c|c|c|c|c|}
\hline \multirow[b]{2}{*}{$\mathrm{Hu}^{\alpha 11-W T}$} & \multirow{2}{*}{ Extracellular domain } & \multirow[t]{2}{*}{ TM } & \multicolumn{2}{|c|}{ Cytoplasmic tail } & \multicolumn{2}{|l|}{ Linker } \\
\hline & & & GFFRS & RRREPGLDPTPKVLE & GTAGPGSIAT & EGFP \\
\hline $\mathrm{Hu}^{\alpha 11-1171}$ & & & GFFRS & GTAGPGSIAT & & \\
\hline
\end{tabular}

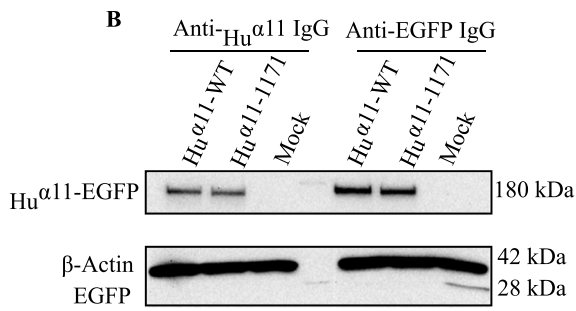

C
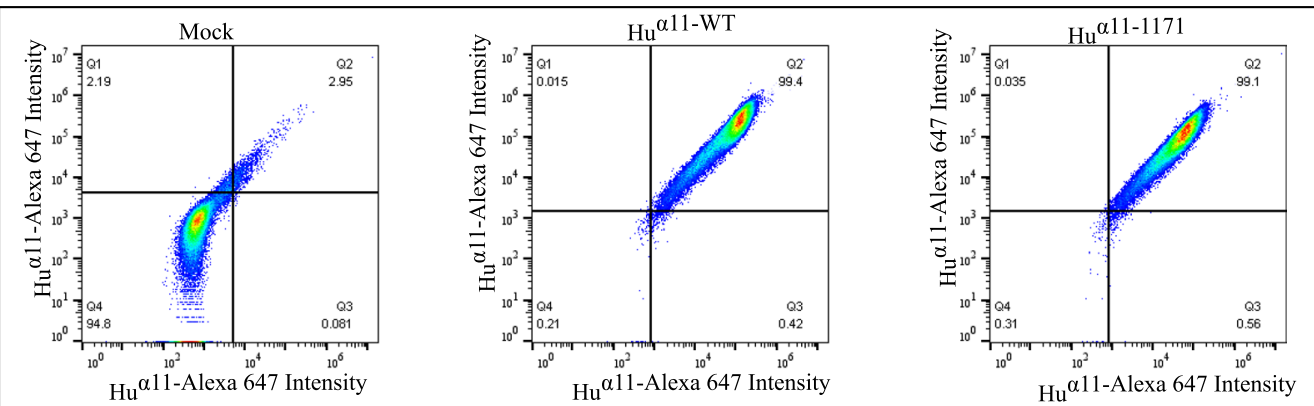

Figure 1. Generation and expression of integrin $\alpha 11$ variants in $\mathrm{C} 2 \mathrm{C} 12$ cells. (A) Schematic illustration showing the amino acid sequences in the linker and the cytoplasmic tail of ${ }_{\mathrm{Hu}} \mathrm{\alpha} 11$ variants. (B) Western blot showing total protein expression of ${ }_{\mathrm{Hu}} \alpha 11$-EGFP in C2C12 cells transfected with $\mathrm{Hu}_{\mathrm{Hu}} \mathrm{11-WT-EGFP}$ and ${ }_{\mathrm{Hu}} \alpha 11-$ 1171-EGFP (full size immunoblot is shown in supplementary) (C). FACS analysis of the cell surface expression $\alpha 11$ in $_{\mathrm{Hu}} \mathrm{\alpha} 11-\mathrm{WT},_{\mathrm{Hu}} \mathrm{\alpha} 11-1171$ and mock transfected cells (Mock).

at different time points revealed that ${ }_{\mathrm{Hu}} \alpha 11-1171$ cells demonstrated less $\mathrm{FAK}^{\mathrm{Y} 397}$ activation than ${ }_{\mathrm{Hu}} \alpha 11-\mathrm{WT}$ cells at 30 and 45 minutes on collagen I (Fig. 3A). Since other collagen-binding integrins have previously been shown to activate MAPK pathways, we investigated activation of ERK, p38 and JNK following attachment of cells to collagen $\mathrm{I}^{34-36}$. Interestingly, ${ }_{\mathrm{Hu}} \mathrm{\alpha} 11-1171$ cells showed a strong reduction in ERK activation compared to ${ }_{\mathrm{Hu}} \alpha 11$-WT cells on collagen I (Fig. 3A). In contrast, activation of $\mathrm{p} 38$ and JNK was not affected by the deletion of the $\alpha 11$ cytoplasmic tail. To confirm the role of integrin $\alpha 11$ in FAK and ERK activation in primary cells, human gingival fibroblasts (hGF) were transfected with control siRNA (Ctrl) or $\alpha 11$ siRNAs (Fig. 3B and supplementary Fig. 3A). The knockdown of $\alpha 11$ did not affect expression of the collagen-binding integrins $\alpha 1$ and $\alpha 2$ chains (Supplementary Fig. 3B,C). Phosphorylated FAK ${ }^{\mathrm{Y} 397}$ and ERK levels were only reduced in $\alpha 11$ siRNA-treated hGF (Fig. 3B and supplementary Fig. 3A). These results demonstrate that cytoplasmic tail of integrin $\alpha 11$ contributes to FAK and ERK activation.

FAK $^{\mathrm{Y} 397}$ activation is involved in integrin $\alpha 11$ cytoplasmic tail-mediated cell proliferation and migration. We next examined if the reduced cell functions observed with the $\alpha 11$-tail-less cells was due to the defect in FAK and ERK activation. Inhibition of FAK ${ }^{\mathrm{Y} 397}$ activation by PF573228 inhibited cell proliferation in both ${ }_{\mathrm{Hu}} \alpha 11-\mathrm{WT}$ and ${ }_{\mathrm{Hu}} \alpha 11-1171$ cells, on collagen I. Similarly, inhibition of ERK activation by U0126 also inhibited $\alpha 11 \beta 1$-mediated cell proliferation on collagen I, implying that both FAK ${ }^{\mathrm{Y} 397}$ and ERK activation are required for $\alpha 11 \beta 1$-mediated cell proliferation (Fig. $4 A$ ). Inhibition of both FAK and ERK activation weakly decreased cell proliferation in ${ }_{\mathrm{Hu}} \mathrm{\alpha} 11$-WT cells on fibronectin, suggesting that cell proliferation mediated by fibronectin-binding integrins is less dependent on these signaling molecules than $\alpha 11 \beta 1$-mediated cell proliferation. In order to understand the overlapping function of FAK and ERK in $\alpha 11 \beta 1$-mediated cell proliferation, we investigated the relationship between FAK and ERK activation. Inhibition of FAK ${ }^{\mathrm{Y} 397}$ activation by PF573228 significantly inhibited ERK activation 30 minutes after cells attached to collagen (Fig. 4B). In contrast, inhibition of ERK activation by $\mathrm{U} 0126$ did not affect $\mathrm{FAK}^{\mathrm{Y} 397}$ activation, indicating that $\mathrm{FAK}^{\mathrm{Y} 397}$ phosphorylation is required for ERK activation.

In spheroid migration assays, inhibition of $\mathrm{FAK}^{\mathrm{Y} 397}$ phosphorylation, completely abrogated migration for both ${ }_{\mathrm{Hu}} \alpha 11-\mathrm{WT}$ and ${ }_{\mathrm{Hu}} \mathrm{\alpha} 11-1171$ cells (Fig. 5A). Contrariwise, inhibition of ERK in spheroid assay did not inhibit 


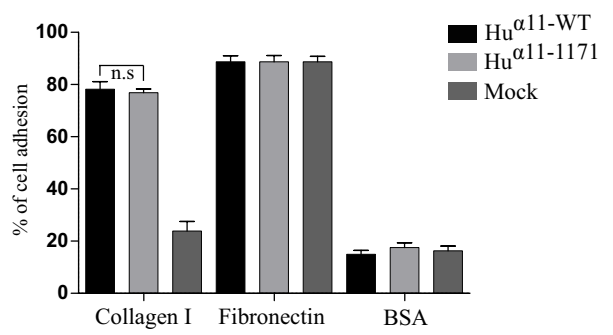

B

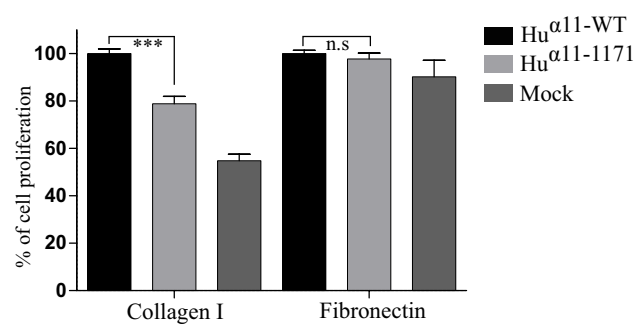

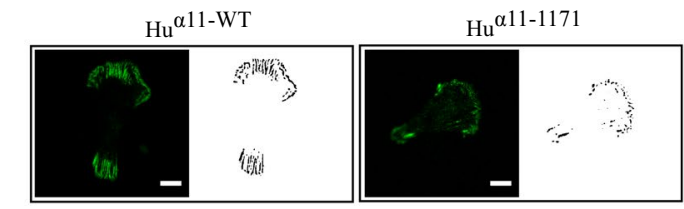
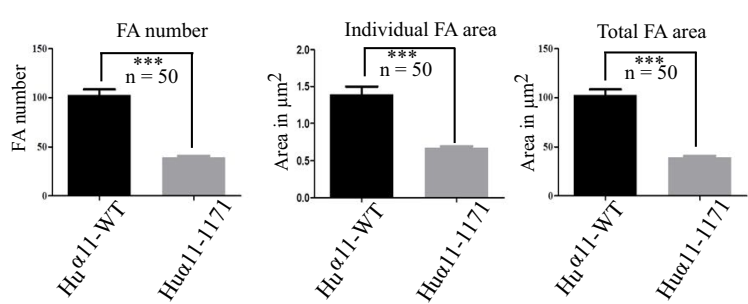

D

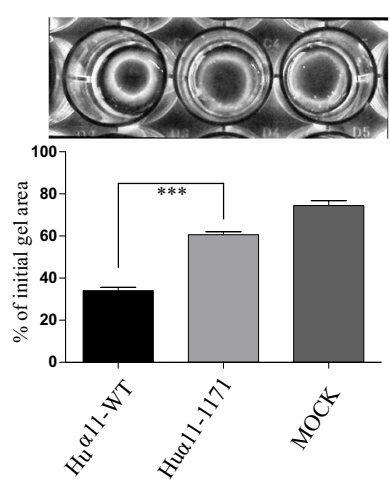

E
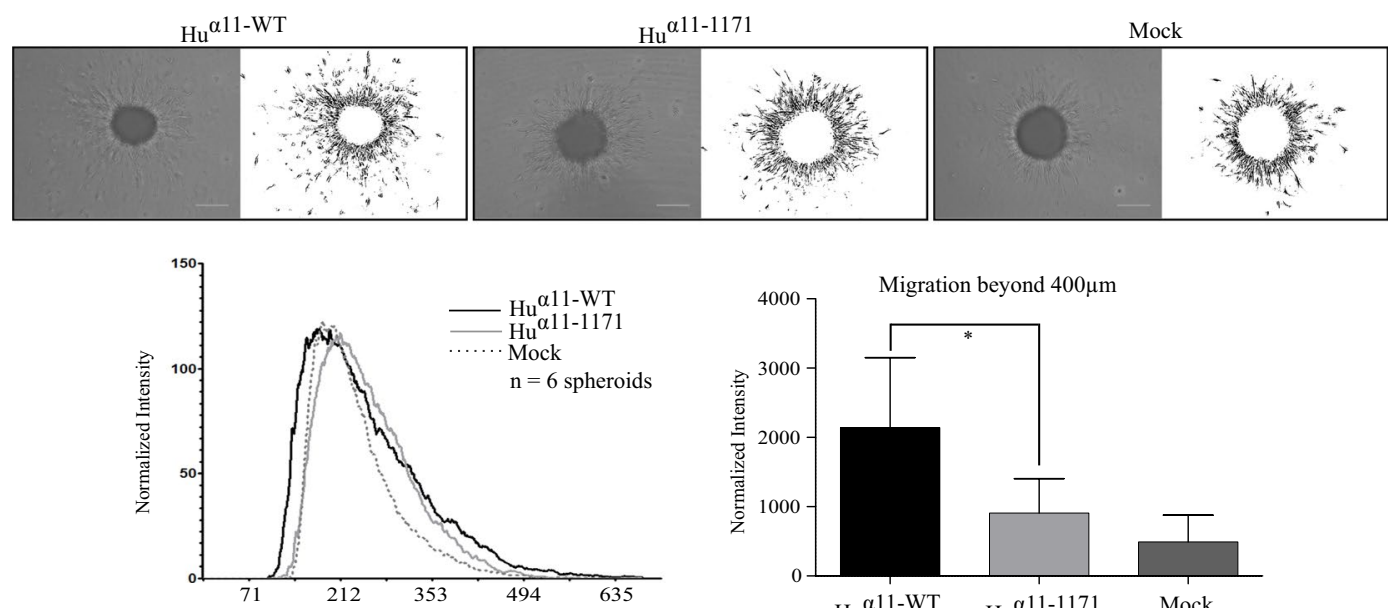

Migration distance from the centre of spheroid in $\mu \mathrm{m}$

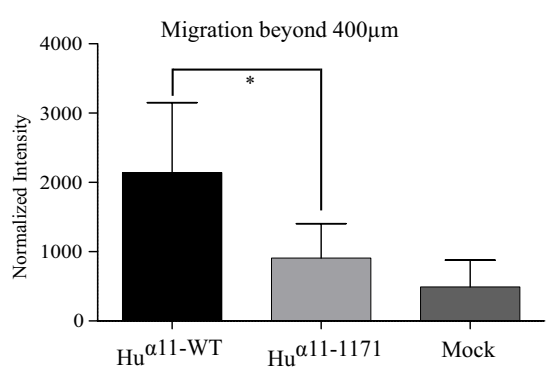

Figure 2. Integrin $\alpha 11$ cytoplasmic tail is not involved in cell adhesion but mediates focal adhesion formation, collagen reorganization, cell migration and cell proliferation. (A) Role of $\alpha 11$-tail in cell adhesion. ${ }_{\mathrm{Hu}} \alpha 11$-WT, ${ }_{\mathrm{Hu}}$ Q11-1171 and mock transfected cells (Mock) were allowed to attach on collagen I or fibronectin or BSA in serum-free conditions for 50 mins. Attached cells were fixed, stained with $0.1 \%$ crystal violet and absorbance was read at $595 \mathrm{~nm}$. (B) Role of $\alpha 11$-tail in cell proliferation. ${ }_{\mathrm{Hu}} \alpha 11-\mathrm{WT}$, $\mathrm{Hu}_{\mathrm{\alpha}} \mathrm{11-1171}$ and Mock cells were allowed to attach on collagen I or fibronectin in reduced serum condition for 24 hours. Attached cells were fixed, stained with $0.1 \%$ crystal violet and absorbance was read at $595 \mathrm{~nm}$. (C) Role of $\alpha 11$ tail in focal adhesion formation. Cells were allowed to attach collagen I for 120 mins. Cells were fixed with 4\% PFA and focal adhesions were imaged using TIRF microscopy and quantified. Scale bar: $10 \mu \mathrm{m}$. (D) Role of $\alpha 11$-tail in collagen reorganization. ${ }_{\mathrm{Hu}} \alpha 11-\mathrm{WT},{ }_{\mathrm{Hu}} \alpha 11-1171$ and Mock cells were mixed with collagen I solution and allowed to contract for 16 hours. Gel diameters were measured, and percentage of initial gel area was calculated. (E) Role of $\alpha 11$-tail in spheroid migration. Homospheroids of ${ }_{\mathrm{Hu}} \alpha 11-\mathrm{WT},{ }_{\mathrm{Hu}} \alpha 11-1171$ and Mock cells were embedded in collagen I gel and spheroid migration was quantified after 24 hours. Radial profile plot depicts the radial cell intensity from the center of the spheroid and the intensity of cells that have migrated beyond $400 \mu \mathrm{m}$ was calculated. Scale bar: $200 \mu \mathrm{m}$. Data shown are pooled from triplicates of at least three independent experiments for cell attachment, cell proliferation and collagen gel contraction. Results were expressed as mean \pm standard deviation of at least three replicates from one representative experiment of at least three independent experiments. Statistical significance was assessed by two tailed, unpaired t-tests and P-values are expressed as $* * * \mathrm{P}<0.001 ; * * \mathrm{P}<0.01$ and $* \mathrm{P}<0.05$. 
A
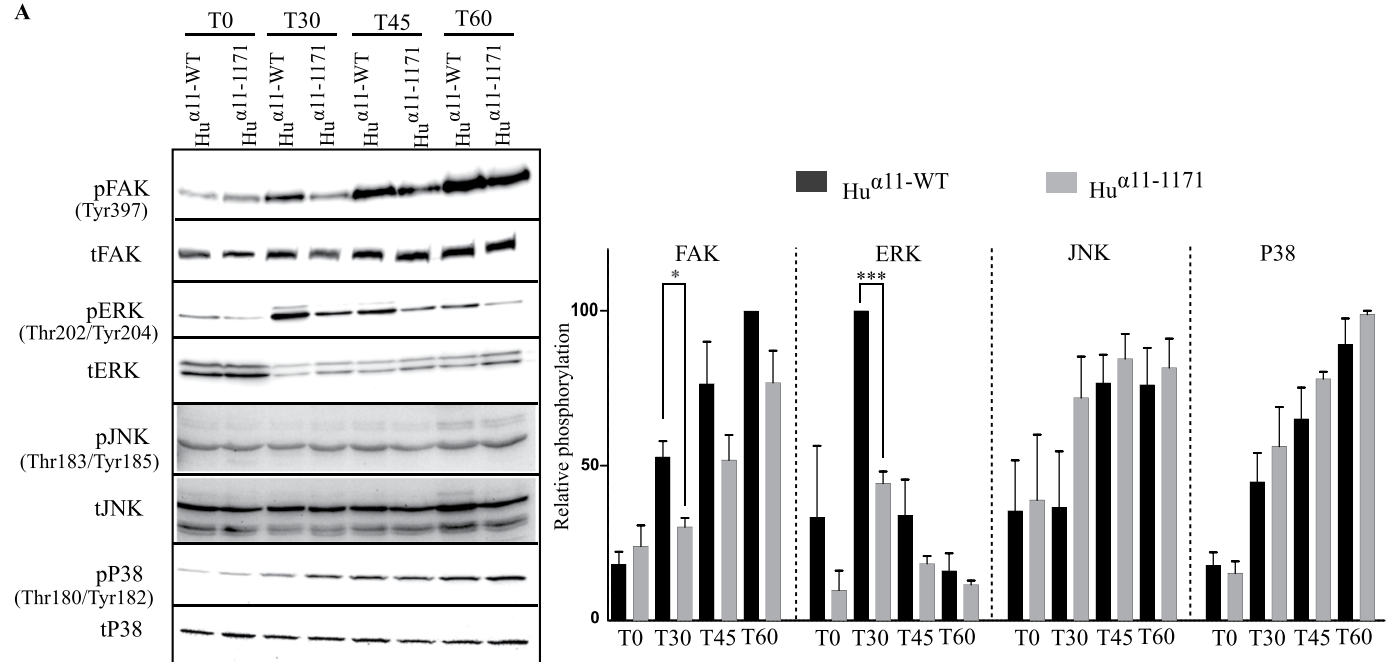

B
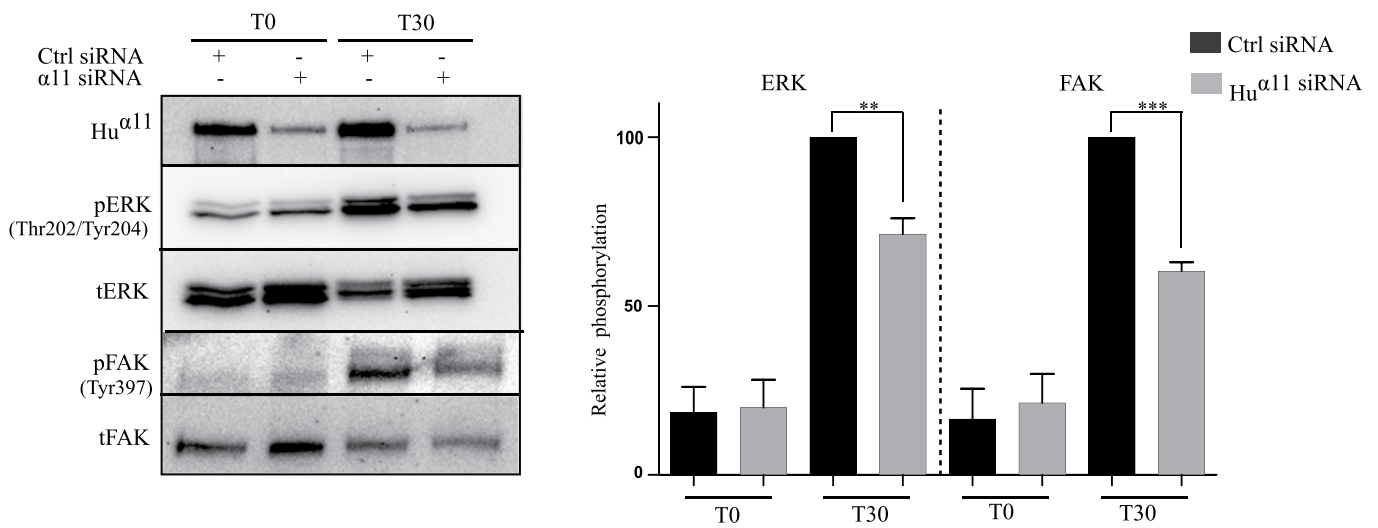

Figure 3. Integrin $\alpha 11$ cytoplasmic tail contributes to FAK and ERK activation. (A) Serum-starved ${ }_{\mathrm{Hu}} \alpha 11$-WT and $\mathrm{Hu}_{\mathrm{H}} \mathrm{\alpha} 1 \mathrm{-1171}$ cells were plated on collagen I in serum-free conditions and cells were lysed at different time points (T0, T30, T45 and T60). Total and phosphorylated levels of FAK ${ }^{\mathrm{Y} 397}$, ERK, p38, JNK were detected by Western blotting and the protein bands were quantified by densitometry analysis (full size immunoblots are shown in supplementary). (B) Human gingival fibroblasts (hGFs) were transfected with control (ctrl) siRNA or $\alpha 11$ siRNA (SMARTpool) and 48 hours post transfection, cells were serum-starved and plated on collagen I in serum-free conditions. After $30 \mathrm{mins}$, cells were lysed, and the lysates were analyzed by western blotting. Protein bands were quantified by densitometry analysis. Statistical significance was assessed by two tailed, unpaired $\mathrm{t}$-tests and $\mathrm{P}$-values are expressed as $* * * \mathrm{P}<0.001 ; * * \mathrm{P}<0.01$ and $* \mathrm{P}<0.05$.

migration beyond $400 \mu \mathrm{m}$ of both ${ }_{\mathrm{Hu}} \mathrm{\alpha} 11-\mathrm{WT}$ and ${ }_{\mathrm{Hu}} \mathrm{\alpha} 11-1171$ cells, suggesting that in contrast to cell proliferation, ERK activation is not involved in integrin $\alpha 11$-mediated cell migration in this 3D model. Furthermore, neither inhibition of $\mathrm{FAK}^{\mathrm{Y} 397}$ activation nor ERK activation inhibited serum-stimulated collagen gel contraction (data not shown).

Since FAK is localized in focal adhesions, we investigated the phosphorylation of $\mathrm{FAK}^{\mathrm{Y} 397}$ in focal adhesions. Similar to our previous results with immunoblotting, we observed significantly reduced amounts of phosphorylated $\mathrm{FAK}^{\mathrm{Y} 397}$ positive adhesions for ${ }_{\mathrm{Hu}} \mathrm{\alpha} 11-1171$ cells as compared to ${ }_{\mathrm{Hu}} \alpha 11$-WT cells (Fig. 5B). These findings suggest that the reduced activation of $\mathrm{FAK}^{\mathrm{Y} 397}$ in $_{\mathrm{Hu}}$ Q11-1171 cells is due to fewer focal adhesions in these cells perse.

To summarize, our results strongly suggest that the cytoplasmic tail of integrin $\alpha 11$ is essential to stabilize focal adhesions that in turn mediate $\mathrm{FAK}^{\mathrm{Y} 397}$ activation involved in cell proliferation and cell migration.

\section{Discussion}

Although integrin cytoplasmic tails are relatively short, they are able to exert control of integrin activity and mediate a number of interactions of importance for integrin function ${ }^{7,8}$. There are in total more than 20 integrins and various research groups have independently deleted cytoplasmic tails and expressed the mutated variants with different results ${ }^{6,37-39}$. When integrin $\beta$-tails are expressed as chimeric proteins with non-integrin 
$\mathbf{A}$

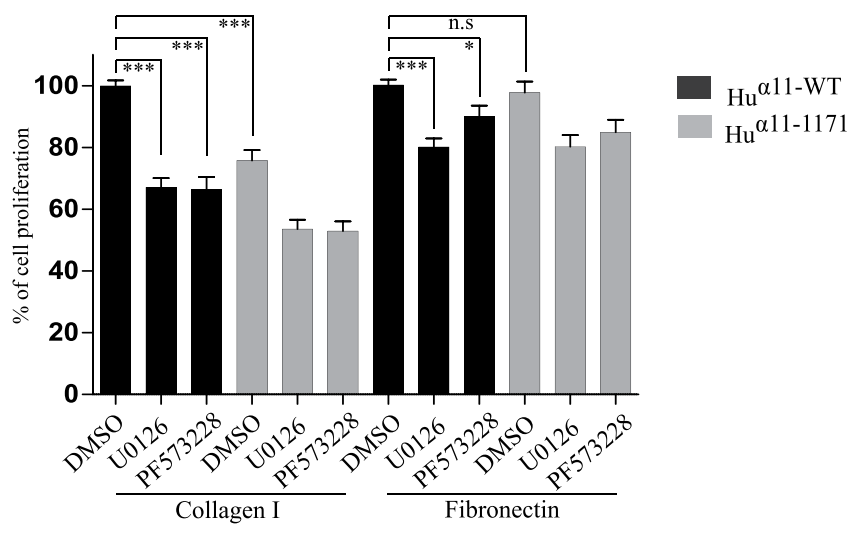

B
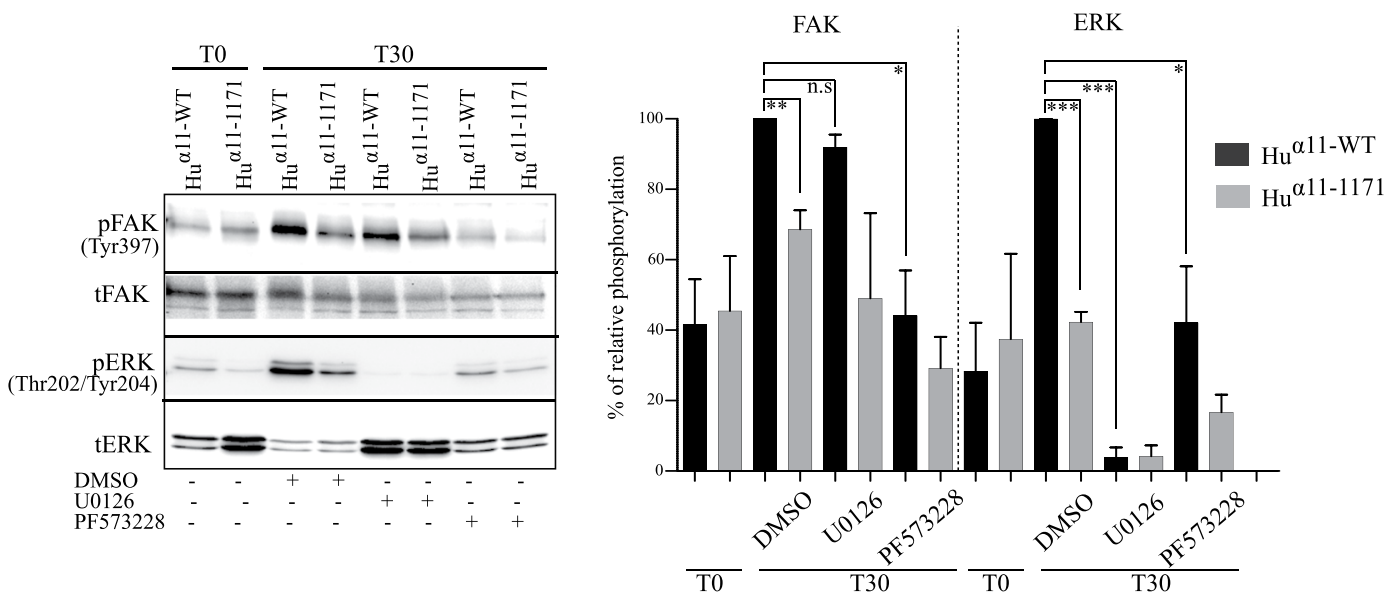

Figure 4. FAK $\mathrm{K}^{\mathrm{Y} 397}$ activation is involved in integrin $\alpha 11$ cytoplasmic tail-mediated cell proliferation and migration. (A) Effect of FAK and ERK inhibition in $\alpha 11$-mediated cell proliferation. $\mathrm{Hu} \alpha 11-\mathrm{WT}$ and $\mathrm{Hu}_{\mathrm{O}} \mathrm{\alpha} 11$ 1171 cells were allowed to attach on collagen I or fibronectin in presence of either DMSO or U0126 $(20 \mu \mathrm{M})$ or PF573228 $(10 \mu \mathrm{M})$ in reduced serum conditions for 24 hours. Attached cells were fixed, stained with $0.1 \%$ crystal violet and absorbance was read at $595 \mathrm{~nm}$. Results were expressed as mean \pm standard deviation of at least three replicates pooled from three independent experiments. (B) Integrin $\alpha 11$ tail-mediated ERK activation is dependent on $\mathrm{FAK}^{\mathrm{Y} 397}$ activation. Serum starved ${ }_{\mathrm{Hu}} \alpha 11-\mathrm{WT}$ and ${ }_{\mathrm{Hu}} \alpha 11-1171$ cells were treated with DMSO or U0126 or PF573228 and allowed to attach on collagen I for 30 minutes. After 30 minutes, cells were lysed, and the lysates were analyzed for total and phosphorylated levels of $\mathrm{FAK}^{\mathrm{Y} 397}$ and ERK by Western blotting. Protein bands were quantified by densitometry analysis and data shown are pooled from at least three independent experiments (Full size immunoblots are shown in supplementary). Statistical significance was assessed by two tailed, unpaired $\mathrm{t}$-tests and $\mathrm{P}$-values are expressed as $* * * \mathrm{P}<0.001 ; * * \mathrm{P}<0.01$ and $* \mathrm{P}<0.05$.

transmembrane- and extracellular parts, the $\beta 1$ integrin tail sequence can direct chimeric proteins into focal adhesions ${ }^{40}$. When integrin $\alpha$-tails are deleted, some $\alpha$-tail-less heterodimers localize to focal adhesions in a ligand-independent manner ${ }^{41-43}$ and often become constitutively activated.

In the current study, we have used EGFP-tagged $\alpha 11$ integrins, in a strategy where the tag is separated by a 10 amino acid linker. Like for EGFP tagged $\alpha 4$ and $\alpha 5$ integrins we find no evidence that addition of the tag interferes with integrin function ${ }^{27,44}$. It could be argued that addition of a tag on tail-less integrin would be more likely to interfere with integrin function than a tag added to full-length integrin. However, independent experiments suggest that the loss of $\alpha 11$ integrin activity seen in the tail-less variant can be duplicated by a specific point mutation in the $\alpha 11$-tail, excluding that non-specific interference of the EGFP-tag (data not shown).

In our present study, we found that deletion of $\alpha 11$ cytoplasmic tail led to reduced focal adhesion formation, reduced cell spreading, reduced collagen gel contraction, reduced cell migration in a $3 \mathrm{D}$ context and reduced ERK-dependent cell proliferation, but that the $\alpha 11$-tail was dispensable for cell adhesion under the conditions used. Deletion of $\alpha 1$ cytoplasmic tail in fibroblastic 3T3 cells leaves cell adhesion to collagen IV unaffected but results in ligand-independent focal contact localization ${ }^{45}$, whereas in endothelial cells $\alpha 1$-tail deletion leads to reduced adhesion to collagen $\mathrm{IV}^{36}$. Deletion of $\alpha 2$ cytoplasmic tail reduces cell adhesion to collagen I in RD rhabdomyosarcoma cells, but this effect can be overcome by ions or ligand concentration, suggesting that a major function of the cytoplasmic $\alpha 2$-tail is to mediate intracellular inside-out activation events, and that $\alpha 2$ deletion effects on cell attachment can be overcome by activating the extracellular domain ${ }^{23}$. The reduced number of focal contacts seen in $\alpha 11$-tail-less expressing cells probably reflects a contribution of $\alpha 11$-tail to a cytoskeletal linkage, 

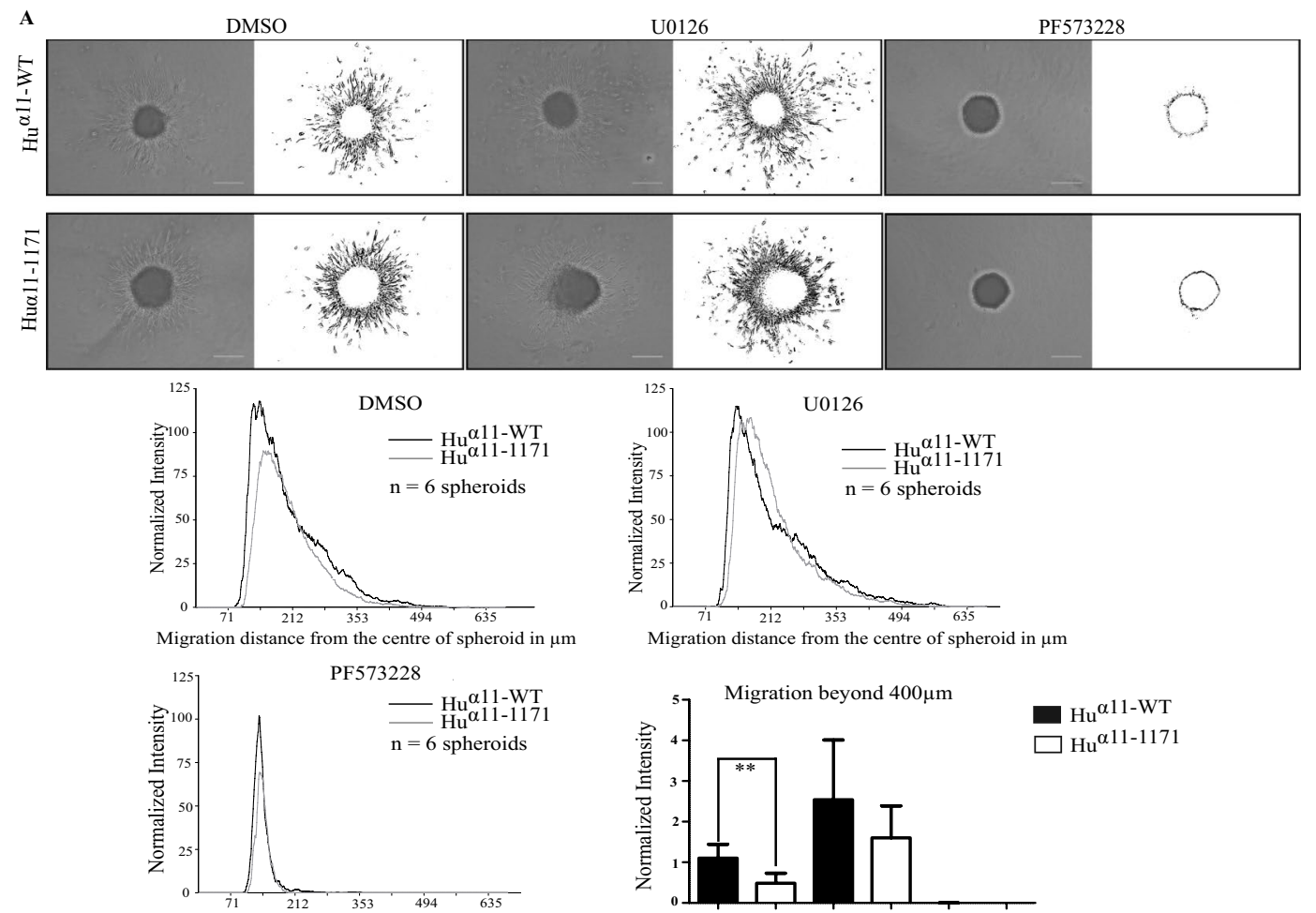

Migration distance from the centre of spheroid in $\mu \mathrm{m}$

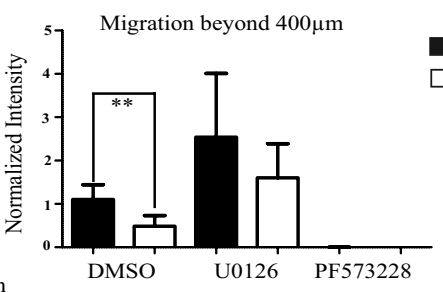

$\mathrm{Hu}^{\alpha 11-W T}$

B
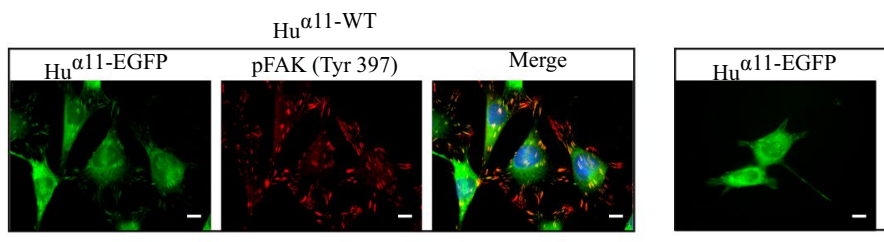

$\mathrm{Hu}^{\alpha 11-1171}$

FA number

Individual FA area
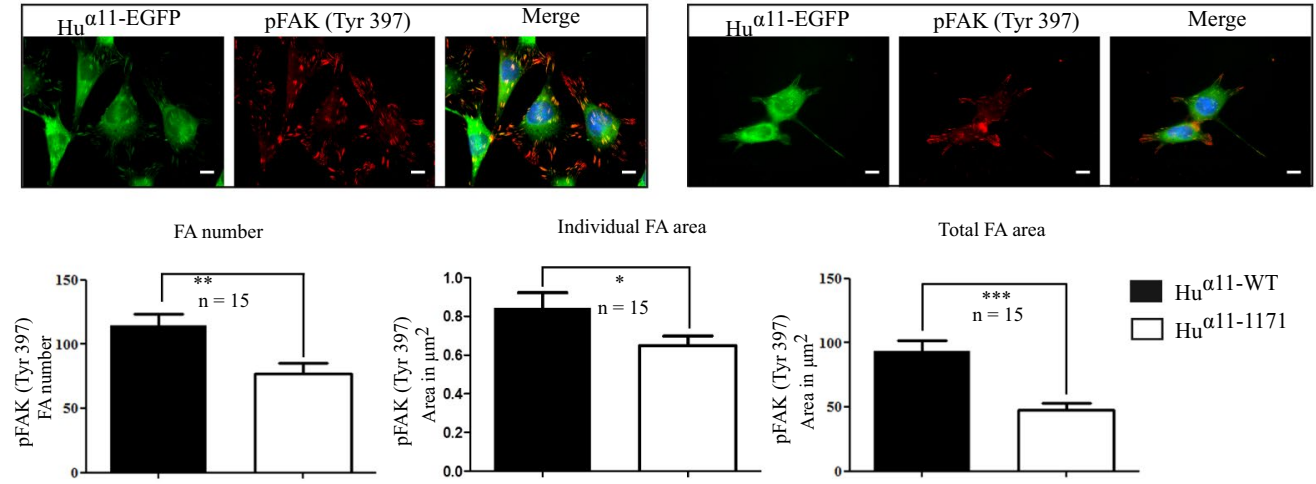

Figure 5. Integrin $\alpha 11$ cytoplasmic tail is involved in focal adhesion formation and $\mathrm{FAK}^{\mathrm{Y} 397}$ activation. (A) Effect of FAK and ERK inhibition in $\alpha 11$-mediated spheroid migration. Homospheroids of ${ }_{\mathrm{Hu}} \alpha 11-\mathrm{WT}$ and ${ }_{\mathrm{Hu}} \alpha 11-1171$ cells were embedded into collagen I gel and treated with either DMSO or U0126 or PF573228. Spheroid migration was quantified after 24 hours. Radial profile plot depicts the radial cell intensity from the center of the spheroid and the intensity of cells that have migrated beyond $400 \mu \mathrm{m}$ was calculated. Scale bar: $200 \mu \mathrm{m}$. (B) Localization of phospho-FAK ${ }^{\mathrm{Y} 397}$ in focal adhesions. ${ }_{\mathrm{Hu}} \alpha 11-\mathrm{WT}$ and ${ }_{\mathrm{Hu}} \alpha 11-1171$ cells were allowed to attach on collagen I for 120 minutes. Cells were fixed with $4 \%$ PFA and stained for phospho-FAK ${ }^{\mathrm{Y} 397}$. Focal adhesions positive for phospho-FAK ${ }^{\mathrm{Y} 397}$ were quantified using ImageJ. Scale bar: $10 \mu \mathrm{m}$. Results were expressed as mean \pm standard deviation of at least three replicates from one representative experiment of at least three independent experiments. Statistical significance was assessed by two tailed, unpaired t-tests and P-values are expressed as $* * * \mathrm{P}<0.001 ; * * \mathrm{P}<0.01$ and $* \mathrm{P}<0.05$.

whose nature remains to be established, rather than need for $\alpha 11$-tail in integrin activation. In vivo integrin $\alpha 2 \beta 1$ is expressed in platelets and hematopoietic cells ${ }^{46}$ where integrin activation is essential, whereas $\alpha 11 \beta 1$ is mainly expressed on fibroblastic cells ${ }^{26}$ where $\beta 1$ integrins are constitutively activated ${ }^{47}$.

Here we showed that interaction of $\alpha 11 \beta 1$ with collagen I mediated ERK signaling. This signaling is thus similar to that observed for $\alpha 1$ (although the preferred ligand for $\alpha 1 \beta 1$ is collagen IV ${ }^{48}$ ), but is different than for $\alpha 2 \beta 1$-mediated signaling, which occurs mainly via p38 in 3D collagen I matrix ${ }^{34}$. Interestingly, in mouse endothelial cells, limited $\alpha 2$-dependent $\mathrm{p} 38$ signaling is observed ${ }^{36}$. These data suggest for collagen-binding integrins that the presence of cell-dependent factors influence which MAPK signaling pathway will be activated upon collagen ligation. siRNA knockdown of $\alpha 11$ reduced FAK and ERK activation, supporting that $\alpha 11$-mediated ERK 
signaling is central in fibroblasts, which is the major cell type expressing $\alpha 11$. Previous studies have demonstrated a11-dependent ERK and PI3K phosphorylation in mesenchymal stem cells expressing multiple collagen-binding integrins ${ }^{49}$. However, in our cell system (C2C12 cells lacking other collagen receptors than the overexpressed $\alpha 11 \beta 1$ ), we failed to detect $\alpha 11$-dependent PI3K activation (data not shown).

Blocking $\alpha 11$-dependent cellular signaling in C2C12 and human gingival fibroblasts cells also blocked ERK-dependent cell proliferation. A majority of the $\alpha 11$-dependent ERK signaling appeared to be dependent on FAK, since FAK inhibition also attenuated the $\alpha 11$-dependent ERK signaling. In the case of $\alpha 1$, FAK independent ERK signaling via Shc has been noted ${ }^{50}$. Later studies have demonstrated that FAK may enhance and prolong integrin-mediated activation of ERK through p130 (CAS), Crk, and Rap1 in cells expressing B-Raf ${ }^{51}$. $\alpha 2$-mediated p38 activation has been suggested to depend on specific residues within the $\alpha 2$ integrin subunit cytoplasmic domain ${ }^{52}$, and independent experiments failed to record FAK activation in 3D collagen gel under conditions of $\alpha 2$-mediated $\mathrm{p} 38$ activation $^{34}$.

To analyze cell migration in $3 \mathrm{D}$ collagen gel we used a spheroid assay. Cell migration ${ }^{53}$, MMP-induction $^{54}$ and collagen gel remodeling ${ }^{55}$ has been shown to depend on ERK signaling in some conditions. In our study, ERK inhibition did not impair cell migration in a collagen matrix. ERK inhibition could attenuate G-protein dependent integrin inhibition as has been reported for $\alpha 2 \beta 1$ integrin-dependent cell migration in smooth muscle cells ${ }^{56}$.

Finally, the collagen gel contraction was not affected by ERK or FAK inhibition suggesting that an alternative signaling pathway is operative in the $\mathrm{C} 2 \mathrm{C} 12$ cells overexpressing $\alpha 11$. We have previously demonstrated that TGF- $\beta$-dependent contraction of floating collagen lattices by dermal fibroblasts depends on $\alpha 11$ - and JNK- signaling ${ }^{19}$. This signaling pathway might be restricted to dermal fibroblasts or depend on relative levels of crucial components in non-canonical TGF- $\beta$ signaling pathway being present in the cells. Previous studies have demonstrated that thrombospondin 1 in scleroderma fibroblasts can activate TGF- $\beta$ to stimulate ERK-dependent collagen contraction ${ }^{57}$. Since $\alpha v \beta 3$ signals via ERK, it is possible that $\alpha v \beta 3$ mediates this collagen gel contraction under these conditions ${ }^{58}$. ERK activation has been shown to stimulate phosphorylation of MLC and in this way contribute to collagen lattice contraction ${ }^{53}$, but in our experiments pharmacological inhibition of ERK in a11-C2C12 cells failed to inhibit contraction.

In summary, our data suggest that the unique functions of $\alpha 11$ that separates it from other collagen-binding integrins is in part due to its cytoplasmic tail, which is needed for efficient focal contact formation, cell spreading, cell proliferation, cell migration and collagen remodeling.

\section{Materials and Methods}

Cell culture. Mouse C2C12 mouse satellite cells were provided by Prof. Anna Starzinski-Powitz (GoetheUniversität, Frankfurt am Main, Germany) and Phoenix 293 cells were provided by Prof. James Lorens, University of Bergen. Primary human gingival fibroblasts (hGF) were isolated from healthy gingival tissues as described earlier ${ }^{59}$. MRC5 human lung fibroblasts (American Type Culture Collection) were obtained from Robert Lafyatis laboratory (University of Pittsburgh Medical Center, Pittsburgh, PA, USA). Cells were cultured at $37^{\circ} \mathrm{C}$ in Dulbecco's modified Eagle's medium (DMEM; Gibco ${ }^{\circledR}$, Invitrogen) with $10 \%$ fetal bovine serum (FBS; Gibco ${ }^{\circledR}$, Invitrogen), $1 \%$ penicillin-streptomycin (PEST; Sigma-Aldrich) and $5 \mu \mathrm{g} / \mathrm{ml}$ plasmocin (InvivoGen). Human gingival fibroblasts were grown from biopsies obtained during oral surgery after obtaining informed consent and in accordance with guidelines and regulations at the Department of Prosthetic Dentistry, Karolinska Institute, Stockholm in the 1990s following approval of experimental protocols by local ethics committee at faculty of Odontology, Karolinska institute and were kindly provided by Prof. Kamal Mustafa (University of Bergen) ${ }^{60}$.

Generation and expression of integrin $\alpha 11$ variants in $\mathrm{C} 2 \mathrm{C} 12$ mouse satellite cells. To construct pBABE ITGA11 retroviral expression constructs, pBABE-puro-Itga11 plasmid, pBJ1- ${ }_{\mathrm{Hu}} \mathrm{\alpha} 11$-WT-EGFP and pBJ1- ${ }_{\mathrm{Hu}} \mathrm{\alpha}$ 11-1171-EGFP (for detail, see Supplementary information) were used as templates. The ITGA11-EGFP cDNAs from $\mathrm{pBJ} 1{ }_{-\mathrm{Hu}} \mathrm{\alpha} 11-\mathrm{WT}$-EGFP and $\mathrm{pBJ1}{ }_{-\mathrm{Hu}} \mathrm{\alpha} 11-1171-\mathrm{EGFP}$ were excised with XhoI (blunted) and EcoRI and subcloned into pBABE-puro-Itga11 plasmid at BamHI (blunted) and EcoRI sites. The constructs were transfected into Phoenix 293 packaging cell line with X-tremeGENE 9 transfection reagent (Roche Diagnostics $\mathrm{GmbH}$ ), according to manufacturer's instructions. The viral supernatant medium was collected after 48 hours post transfection. $\mathrm{C} 2 \mathrm{C} 12$ cells, cultured on 6 -well plates were infected with viral supernatants containing polybrene at $5 \mu \mathrm{g} / \mathrm{ml}$ by spinfection at $1200 \mathrm{~g}$ for 90 minutes. After 36 hours, the culture medium was changed to a selection medium containing $2 \mu \mathrm{g} / \mathrm{ml}$ of puromycin. In addition, the cell populations with similar levels of EGFP intensity were sorted by Fluorescence-activated cell sorting (FACS).

Estimation of cell surface protein expression by FACS. FACS was performed at The Molecular Imaging Centre (MIC), University of Bergen. Cells were detached with Trypsin-EDTA (0.05\% Trypsin and $0.02 \%$ EDTA; Gibco ${ }^{\circledR}$, Invitrogen) and neutralized with DMEM containing $10 \%$ FBS. The cell suspension was filtered with a $40 \mu \mathrm{m}$ syringe filter and $2 \times 10^{6}$ cells were used for the analysis. Cells were washed twice with PBS for 5 minutes at $210 \times$ g with phosphate buffered saline (PBS) and the cell pellet was fixed with $2 \%$ paraformaldehyde/ PBS for 10 minutes. After fixation, cells were washed three times with PBS and blocked with $2 \%$ Bovine serum albumin (BSA/PBS) for 30 minutes in room temperature (RT). Cells were incubated with mouse anti- ${ }_{\mathrm{Hu}} \alpha 11$ IgG $(\mathrm{mAb} 203 \mathrm{E} 3)^{61}$ at a final concentration of $5 \mu \mathrm{g} / \mathrm{ml}$ in $2 \%$ BSA/PBS for 60 minutes at $37^{\circ} \mathrm{C}$. After washing three times with PBS, cells were incubated with goat anti-mouse IgG conjugated with Alexa fluor ${ }^{\circledR} 647$ for 60 minutes in RT. Cells were washed 3X with PBS and analyzed using FACS Accuri for the intensity of Alexa fluor ${ }^{\circledR} 647$ by using uniform gating for all samples and data was analyzed using FLOWJO computer software for FACS analysis (FLOWJO, LLC). 
Cell adhesion assay. Forty-eight-well plates were coated with fibronectin $\left(1 \mu \mathrm{g} / \mathrm{cm}^{2}\right.$ : Sigma-Aldrich $)$ or collagen type I $\left(5 \mu \mathrm{g} / \mathrm{cm}^{2}\right.$ : Bovine PureCol ${ }^{\circledR}$, Advanced BioMatrix $)$ and incubated for 2 hours at $37^{\circ} \mathrm{C}$. After washing with PBS, the plates were blocked with $2 \%$ BSA for 1 hour at $37^{\circ} \mathrm{C}$. Cells were washed three times with DMEM and $1 \times 10^{5}$ cells/well were cultured for 50 minutes at $37^{\circ} \mathrm{C}$. Unattached cells were removed carefully by washing three times with PBS containing $\mathrm{Ca}^{2+}$ and $\mathrm{Mg}^{2+}$. Cells were then fixed with $96 \%$ ethanol for 10 minutes at room temperature followed by staining with $0.1 \%$ crystal violet for 20 minutes at room temperature. Plates were washed three times with distilled water and the cells were lysed with $1 \%$ Triton X-100 for 5 minutes. The lysates were transferred to a 96-well plate and absorbance was read at $595 \mathrm{~nm}$.

Cell proliferation assay. Cells were seeded on 24 -well plates coated with fibronectin $\left(1 \mu \mathrm{g} / \mathrm{cm}^{2}\right)$ or collagen type I $\left(5 \mu \mathrm{g} / \mathrm{cm}^{2}\right)$ and cultured for 24 hours in DMEM containing 1\% FBS. Cells were washed with PBS and fixed with $96 \%$ ethanol for 10 minutes at room temperature followed by staining with $0.1 \%$ crystal violet for 20 minutes at room temperature. After washing three times with distilled water, the cells were lysed with $1 \%$ Triton X-100 for 5 minutes and lysates were transferred to a 96-well plate. The absorbance was read at $595 \mathrm{~nm}$. For inhibition

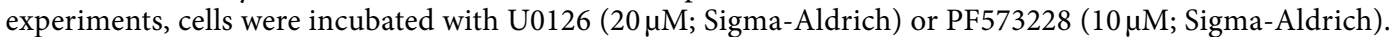
Data were normalized considering proliferation of wild-type cells as $100 \%$ on collagen and fibronectin.

Collagen gel contraction. Collagen gel contraction was performed as described earlier ${ }^{28,59}$. In brief, 24-well plates were blocked with $2 \% \mathrm{BSA}$, overnight at $37^{\circ} \mathrm{C}$ and then washed three times with PBS. Collagen solution was prepared by mixing 5 parts of DMEM $2 \times($ SLM-202-B, Merck Millipore), one part of 0.2 M Hepes at pH.8.0 and 4 parts of Collagen I ( $3 \mathrm{mg} / \mathrm{ml}$; Bovine PureCol ${ }^{\circledR}$, Advanced BioMatrix). Collagen solution was then mixed with cells to obtain a final concentration of $1 \times 10^{5} \mathrm{cells} / \mathrm{ml}$. To each well, $400 \mu \mathrm{l}$ of cell-collagen suspension was added and allowed to polymerize for 90 minutes at $37^{\circ} \mathrm{C}$. Polymerized collagen gels were floated with $400 \mu \mathrm{l}$ of DMEM containing $0.5 \%$ FBS. Gel diameters were measured using a ruler and the percentage of the initial gel area was calculated.

Immunocytofluorescence. Glass bottom dishes ( $3.5 \mathrm{~mm}$, MatTek) were coated with collagen type I ( $50 \mu \mathrm{g} /$ $\mathrm{cm}^{2}$ ) for 60 minutes at $37^{\circ} \mathrm{C}$. Dishes were washed three times with PBS and $2 \times 10^{5}$ cells were cultured for 2 hours in DMEM with 10\% FBS. Cells were then fixed with 4\% paraformaldehyde/PBS for 10 minutes at RT and followed by washing three times with PBS for 5 minutes per wash. Focal adhesion images were captured using Nikon Total Internal Reflection Microscope (TIRFM).

For phospho $\mathrm{FAK}^{\mathrm{Y} 397}$ staining experiments, coverslips $(12 \mathrm{~mm}, 1.5 \mathrm{H}$; Marienfeld) were coated in 24-well plates with collagen type I $\left(50 \mu \mathrm{g} / \mathrm{cm}^{2}\right)$ for 60 minutes at $37^{\circ} \mathrm{C}$. Cover slips were washed three times and blocked with $2 \% \mathrm{BSA} / \mathrm{PBS}$ for 1 hour at $37^{\circ} \mathrm{C}$. Later, $4 \times 10^{4}$ cells were seeded per well in serum-free conditions. Cells were cultured for 2 hours and fixed with $4 \%$ paraformaldehyde/PBS for 10 minutes at RT. Cells were permeabilized in $0.5 \%$ Triton X-100 /PBS buffer for 5 minutes and blocked with 5\% BSA/PBS containing $0.1 \%$ Triton X-100 for 1 hour at RT. Next, cover slips were incubated with polyclonal rabbit anti-phospho FAK ${ }^{\mathrm{Y} 397}$ IgG ( $1: 400 ; 44-624$, Biosource) in 5\% BSA/PBS with $0.1 \%$ Triton X-100 for 1 hour at $37^{\circ} \mathrm{C}$. After washing with $0.05 \%$ Tween-20/PBS, cover slips were incubated with Alexa fluor ${ }^{\circledR} 594$ conjugated goat anti-rabbit IgG (1:400, Jackson ImmunoResearch) for 1 hour at RT. Later, coverslips were incubated with DAPI $(0.25 \mu \mathrm{g} / \mathrm{ml}$, Invitrogen $)$ and mounted with ProLong Diamond Antifade mounting medium (Thermo Scientific). Cells were visualized under a Zeiss Axioscope fluorescence microscope and pictures were acquired with a digital AxioCam MRm camera.

Spheroid preparation and migration assay in 3D collagen gel. Homospheroids were made with C2C12 cells using hanging drop method as described earlier ${ }^{62}$. In short, C2C12 cells were harvested and suspended in culture medium to have a final concentration of $1 \times 10^{6}$ cells $/ \mathrm{ml}$. Approximately, 28 drops of cell suspension $\left(25 \mu \mathrm{l} / \mathrm{drop} ; 2.5 \times 10^{4}\right.$ cells) were made on the lid of a $10 \mathrm{~cm}$ Petri dish, containing cell culture medium. The lid was carefully inverted over the Petri dish bottom, without disturbing the drop form. The spheroids were cultured for 3 days under regular cell culture conditions. Collagen I solution was prepared as described in collagen gel contraction assay and $100 \mu \mathrm{l}$ of collagen I solution was added onto a 96-well plate and incubated for 15 minutes at $37^{\circ} \mathrm{C}$. One spheroid was embedded per well and the spheroid-collagen gel was allowed to polymerize for 90 minutes at $37^{\circ} \mathrm{C}$. After polymerization, $100 \mu \mathrm{LMEM}$ was added to each well and cultured for 24 hours. Spheroids were visualized under an inverted light microscope (Leica DMIL) and images were captured. When indicated, DMSO or $20 \mu \mathrm{M}$ U0126 or $10 \mu \mathrm{M}$ PF573228 were added to the medium.

SDS-PAGE and western blotting. Cells were seeded on 6-well plates and cultured until confluency. Later, cells were lysed with buffer containing $0.5 \%$ Nonidet P-40, $20 \mathrm{mM}$ Tris- $\mathrm{HCl}$ pH7.4, $150 \mathrm{mM} \mathrm{NaCl}, 1 \mathrm{mM} \mathrm{MgCl}{ }_{2}$, $1 \mathrm{mM} \mathrm{CaCl}_{2}$ and proteinase inhibitor complete (Roche, Germany). Protein concentration was determined by BCA assay. Protein samples of $20 \mu \mathrm{g}$ from each clone, mixed with SDS sample buffer (Biorad) containing $2 \%$ of 2- $\beta$-mercaptoethanol were loaded and separated by $6 \%$ SDS-polyacrylamide gel. Then, the purified proteins were transferred to a PVDF membrane using iBlot ${ }^{\circledR}$ system (Invitrogen). Membranes were analyzed with mouse anti-EGFP IgG (1:2000, Clonetech) or polyclonal rabbit anti- ${ }_{\mathrm{Hu}} \alpha 11$ IgG (PA5-23897, Thermo Fischer Scientific) or mouse anti- $\beta$-actin IgG (1:5000, Sigma-Aldrich). Blots were developed using ECL system (Pierce protein research products) and ChemiDoc XRS (Bio-Rad).

For signaling experiments, cells were cultured overnight with reduced serum conditions ( $1 \% \mathrm{FBS})$ and serum starved for 3 hours before the experiments. Trypsinized cells were neutralized with DMEM containing Soyabean trypsin inhibitor $(50 \mu \mathrm{g} / \mathrm{ml})$. Cells were washed three times with DMEM and incubated for 45 minutes on rotator at RT. $10^{6}$ cells were seeded on to 6 -well plates pre-coated with collagen $\left(5 \mu \mathrm{g} / \mathrm{cm}^{2}\right)$ and blocked with $2 \%$ BSA/PBS, as described previously. For T0 samples, cells were lysed directly with 1X SDS sample buffer. For the remaining samples, cells in each were lysed in $1 X$ SDS sample buffer after $30 \mathrm{~min}$ (T30), $45 \mathrm{~min}$ (T45) and $60 \mathrm{~min}$ 
(T60). Protein lysates were separated by SDS-PAGE and analyzed by western blotting using the following antibodies: Rabbit monoclonal anti-phospho p44/42 MAPK IgG (20G11), rabbit monoclonal anti-p44/42 MAPK IgG (137F5), rabbit anti-FAK IgG (\#3285), rabbit monoclonal anti-phospho-SAPK/JNK IgG (81E11), rabbit anti-SAPK/JNK IgG (\#9252), mouse monoclonal anti-phospho p38 IgG (28B10), rabbit anti-p38 IgG (\#9212) from Cell Signaling Technology and rabbit anti-phospho FAKY397 IgG from Biosource. Relative protein expression was quantified using Image $\mathrm{Lab}^{\mathrm{TM}}$ Software (Bio-Rad).

Integrin $\alpha 11$ silencing with siRNA. Primary hGFs were harvested and $5 \times 10^{5}$ cells were plated on $10 \mathrm{~cm}$ culture dishes $30 \mathrm{~min}$ prior to transfection. Cells were transfected with SMARTpool ON-TARGET plus ITGA11 siRNA (L-008000-00-0005, Dharmacon) or Individual ON-TARGET plus ITGA11 (J-008000-10, Dharmacon) or ON-TARGET plus Non-Targeting siRNA (D-001810-02-05, Dharmacon) at a final concentration of $20 \mathrm{nM}$ with HiPerfect transfection reagent. After 48 hours, cells were serum starved for overnight. Cells were prepared as described for signaling experiments. Six-well plates were coated with thin film fibrillar collagen I gel prepared using the collagen I solution described in collagen gel contraction section and allowed to polymerize for $60 \mathrm{~min}$ at $37^{\circ} \mathrm{C}$. Cells were harvested and $5 \times 10^{5}$ cells were plated on to each 6 -well and lysed as described above for SDS-PAGE and Western blotting analysis. Western blots stained with anti-phospho p44/42 MAPK IgG were reprobed with a custom-made mouse monoclonal anti- ${ }_{\mathrm{Hu}} \mathrm{\alpha} 11 \mathrm{IgG}, \mathrm{mAb} 210 \mathrm{~F} 4$ (Supplementary Fig. 1) to confirm the silencing of ITGA11. In addition, membranes were analyzed with rabbit monoclonal anti-human $\alpha 2$ (EPR 5788, Abcam), mouse monoclonal anti-human $\alpha 1$ antibody (MAB 5676, R\&D Systems), mouse GAPDH antibody 6C5 (sc-32233, Santa cruz biotechnology) and mouse anti- $\beta$-actin IgG (AC-74, Sigma-Aldrich) to confirm the unchanged levels of integrin $\alpha 1$ or $\alpha 2$ protein. MRC5 protein lysates were used as positive controls.

Image analysis. Focal adhesions were quantified as described previously ${ }^{63}$. Briefly, raw images were subjected to background correction with a rolling ball radius of 50 using ImageJ. Image contrast was enhanced using ImageJ plugin CLAHE and threshold adjusted. The number of focal adhesions, area of individual focal adhesion and total area of focal adhesions were quantified for a single cell. Cell spreading was quantified by measuring the cell surface area, which was in turn calculated by drawing the cell boundary using ImageJ. Spheroid images were also subjected to background correction and contrast enhancement using CLAHE plugin in ImageJ. Threshold adjusted images were used to quantify the radial cell density profile from the center of the spheroid, using the Radial Profile plugin from ImageJ. The cell densities of migrated cells at different distant points were used to quantify the distance of migration from the center of the spheroid as described earlier ${ }^{64}$.

Statistical analysis. Statistical significance was assessed by using two tailed, unpaired t-tests as indicated in the figure legends and $\mathrm{P}<0.05$ considered statistically significant. Statistical analysis and all graphs were done using GraphPad Prism 5 software (GraphPad Inc, USA). Data normalization was done based on maximum value in each experiment and data from three independent experiments was pooled together, and average \pm standard deviation was calculated for each cell type and condition. For cell adhesion assay, data normalization was done based on the average absorbance values of the fibronectin-coated wells in each experiment.

\section{Data availability}

No datasets were generated or analyzed during the current study.

Received: 17 April 2019; Accepted: 10 September 2019;

Published online: 25 October 2019

\section{References}

1. Barczyk, M., Carracedo, S. \& Gullberg, D. Integrins. Cell Tissue Res 339, 269-280, https://doi.org/10.1007/s00441-009-0834-6 (2010).

2. Morse, E. M., Brahme, N. N. \& Calderwood, D. A. Integrin cytoplasmic tail interactions. Biochemistry 53, 810-820, https://doi. $\operatorname{org} / 10.1021 /$ bi401596q (2014).

3. Velling, T., Kusche-Gullberg, M., Sejersen, T. \& Gullberg, D. cDNA cloning and chromosomal localization of human alpha11 integrin. A collagen-binding, I domain-containing, betal-associated integrin alpha-chain present in muscle tissues. J. Biol. Chem. 274, 25735-25742 (1999).

4. Rantala, J. K. et al. SHARPIN is an endogenous inhibitor of betal-integrin activation. Nat Cell Biol 13, 1315-1324, https://doi. org/10.1016/0026-0495(88)90105-9 (2011).

5. O'Toole, T. E. et al. Modulation of the affinity of integrin alpha IIb beta 3 (GPIIb-IIIa) by the cytoplasmic domain of alpha IIb. Science 254, 845-847 (1991).

6. O’Toole, T. E. et al. Integrin cytoplasmic domains mediate inside-out signal transduction. J Cell Biol 124, 1047-1059 (1994).

7. Legate, K. R. \& Fassler, R. Mechanisms that regulate adaptor binding to beta-integrin cytoplasmic tails. J Cell Sci 122, 187-198 (2009).

8. Moser, M., Legate, K. R., Zent, R. \& Fassler, R. The tail of integrins, talin, and kindlins. Science 324, 895-899, https://doi.org/10.1126/ science.1163865 (2009).

9. Calderwood, D. A., Campbell, I. D. \& Critchley, D. R. Talins and kindlins: partners in integrin-mediated adhesion. Nat Rev Mol Cell Biol 14, 503-517, https://doi.org/10.1038/nrm3624 (2013).

10. Pankov, R. et al. Integrin dynamics and matrix assembly: tensin-dependent translocation of alpha(5)beta(1) integrins promotes early fibronectin fibrillogenesis. J Cell Biol 148, 1075-1090 (2000).

11. Liu, J. et al. Structural mechanism of integrin inactivation by filamin. Nat Struct Mol Biol 22, 383-389, https://doi.org/10.1038/ nsmb.2999 (2015).

12. Liu, J., Wang, Z., Thinn, A. M., Ma, Y. Q. \& Zhu, J. The dual structural roles of the membrane distal region of the alpha-integrin cytoplasmic tail during integrin inside-out activation. J Cell Sci 128, 1718-1731, https://doi.org/10.1242/jcs.160663 (2015).

13. De Franceschi, N. \& Ivaska, J. Integrin bondage: filamin takes control. Nat Struct Mol Biol 22, 355-357, https://doi.org/10.1038/ nsmb.3024 (2015). 
14. Li, H. et al. Structural basis of kindlin-mediated integrin recognition and activation. Proc Natl Acad Sci USA 114, 9349-9354, https:// doi.org/10.1073/pnas.1703064114 (2017).

15. Zeltz, C. \& Gullberg, D. The integrin-collagen connection - a glue for tissue repair? J. Cell Sci. 129, 653-664, https://doi.org/10.1242/ jcs.180992 (2016)

16. Zeltz, C., Lu, N. \& Gullberg, D. Integrin alpha11beta1: a major collagen receptor on fibroblastic cells. Adv Exp Med Biol 819, 73-83, https://doi.org/10.1007/978-94-017-9153-3_5(2014).

17. Gullberg, D., Velling, T., Sjoberg, G. \& Sejersen, T. Up-regulation of a novel integrin alpha-chain (alpha mt) on human fetal myotubes. Dev Dyn 204, 57-65, https://doi.org/10.1002/aja.1002040108 (1995).

18. Popova, S. N. et al. Alpha11 betal integrin-dependent regulation of periodontal ligament function in the erupting mouse incisor. Mol Cell Biol 27, 4306-4316, https://doi.org/10.1128/MCB.00041-07 (2007).

19. Schulz, J. N. et al. Reduced granulation tissue and wound strength in the absence of alphal1betal integrin. J Invest Dermatol 135, 1435-1444, https://doi.org/10.1038/jid.2015.24 (2015).

20. Navab, R. et al. Integrin alpha1lbetal regulates cancer stromal stiffness and promotes tumorigenicity and metastasis in non-small cell lung cancer. Oncogene 35, 1899-1908, https://doi.org/10.1038/onc.2015.254 (2016).

21. Schulz, J. N. et al. New developments on skin fibrosis - Essential signals emanating from the extracellular matrix for the control of myofibroblasts. Matrix Biol 68-69, 522-532, https://doi.org/10.1016/j.matbio.2018.01.025 (2018).

22. Romaine, A. et al. Overexpression of integrin alpha11 induces cardiac fibrosis in mice. Acta Physiol (Oxf) 222, https://doi. org/10.1111/apha.12932 (2018).

23. Kawaguchi, S. \& Hemler, M. E. Role of the alpha subunit cytoplasmic domain in regulation of adhesive activity mediated by the integrin VLA-2. J Biol Chem 268, 16279-16285 (1993).

24. Chan, B. M. et al. Distinct cellular functions mediated by different VLA integrin alpha subunit cytoplasmic domains. Cell 68, 1051-1060, https://doi.org/10.1016/0092-8674(92)90077-p (1992).

25. Thinn, A. M. M., Wang, Z. \& Zhu, J. The membrane-distal regions of integrin alpha cytoplasmic domains contribute differently to integrin inside-out activation. Sci Rep 8, 5067, https://doi.org/10.1038/s41598-018-23444-w (2018).

26. Popova, S. N. et al. The mesenchymal alphal lbeta1 integrin attenuates PDGF-BB-stimulated chemotaxis of embryonic fibroblasts on collagens. Dev Biol 270, 427-442, https://doi.org/10.1016/j.ydbio.2004.03.006 (2004).

27. Laukaitis, C. M., Webb, D. J., Donais, K. \& Horwitz, A. F. Differential dynamics of alpha 5 integrin, paxillin, and alpha-actinin during formation and disassembly of adhesions in migrating cells. J Cell Biol 153, 1427-1440, https://doi.org/10.1083/jcb.153.7.1427 (2001).

28. Tiger, C. F., Fougerousse, F., Grundstrom, G., Velling, T. \& Gullberg, D. alpha1 lbetal integrin is a receptor for interstitial collagens involved in cell migration and collagen reorganization on mesenchymal nonmuscle cells. Dev Biol 237, 116-129, https://doi. org/10.1006/dbio.2001.0363 (2001).

29. Klein, C. E. et al. Integrin alpha 2 beta 1 is upregulated in fibroblasts and highly aggressive melanoma cells in three-dimensional collagen lattices and mediates the reorganization of collagen I fibrils. J Cell Biol 115, 1427-1436 (1991).

30. Kornberg, L., Earp, H. S., Parsons, J. T., Schaller, M. \& Juliano, R. L. Cell adhesion or integrin clustering increases phosphorylation of a focal adhesion-associated tyrosine kinase. J Biol Chem 267, 23439-23442 (1992).

31. Parsons, J. T. et al. Focal adhesion kinase: structure and signalling. J Cell Sci Suppl 18, 109-113 (1994).

32. Schaller, M. D. et al. Autophosphorylation of the focal adhesion kinase, pp125FAK, directs SH2-dependent binding of pp60src. Mol Cell Biol 14, 1680-1688 (1994).

33. Horton, E. R. et al. Modulation of FAK and Src adhesion signaling occurs independently of adhesion complex composition. J Cell Biol 212, 349-364, https://doi.org/10.1083/jcb.201508080 (2016).

34. Ivaska, J. et al. Integrin alpha2betal mediates isoform-specific activation of $\mathrm{p} 38$ and upregulation of collagen gene transcription by a mechanism involving the alpha2 cytoplasmic tail. J Cell Biol 147, 401-416 (1999).

35. Klekotka, P. A., Santoro, S. A. \& Zutter, M. M. alpha 2 integrin subunit cytoplasmic domain-dependent cellular migration requires p38 MAPK. J Biol Chem 276, 9503-9511, https://doi.org/10.1074/jbc.M006286200 (2001).

36. Abair, T. D. et al. Functional analysis of the cytoplasmic domain of the integrin \{alpha\}1 subunit in endothelial cells. Blood 112, 3242-3254, https://doi.org/10.1182/blood-2007-12-126433 (2008).

37. Chan, B. M. et al. Distinct cellular functions mediated by different VLA integrin a subunit cytoplasmic domains. Cell 68, 1051-1060 (1992).

38. Kassner, P. D., Kawaguchi, S. \& Hemler, M. E. Minimum alpha chain cytoplasmic tail sequence needed to support integrin-mediated adhesion. J Biol Chem 269, 19859-19867 (1994).

39. Li, X. et al. Requirements for the cytoplasmic domain of the aPS1, aPS2 and bPS integrin subunits during Drosophila development. Development 125, 701-711 (1998).

40. LaFlamme, S. E., Akiyama, S. K. \& Yamada, K. M. Regulation of fibronectin receptor distribution. J Cell Biol 117, 437-447 (1992).

41. Briesewitz, R., Epstein, M. R. \& Marcantonio, E. E. Expression of native and truncated forms of the human integrin al subunit. J. Biol. Chem. 268, 2989-2996 (1993).

42. Ylanne, J. et al. Distinct functions of integrin alpha and beta subunit cytoplasmic domains in cell spreading and formation of focal adhesions. J Cell Biol 122, 223-233 (1993).

43. Kawaguchi, S., Bergelson, J. M., Finberg, R. W. \& Hemler, M. E. Integrin alpha 2 cytoplasmic domain deletion effects: loss of adhesive activity parallels ligand-independent recruitment into focal adhesions. Mol Biol Cell 5, 977-988, https://doi.org/10.1091/mbc.5.9.977 (1994).

44. Pinco, K. A., He, W. \& Yang, J. T. alpha4beta1 integrin regulates lamellipodia protrusion via a focal complex/focal adhesionindependent mechanism. Mol Biol Cell 13, 3203-3217, https://doi.org/10.1091/mbc.02-05-0086 (2002).

45. Briesewitz, R., Kern, A. \& Marcantonio, E. E. Ligand-dependent and -independent integrin focal contact localization: the role of the alpha chain cytoplasmic domain. Mol Biol Cell 4, 593-604 (1993).

46. Zutter, M. M. \& Santoro, S. A. Widespread histologic distribution of the alpha 2 beta 1 integrin cell-surface collagen receptor. Am J Pathol 137, 113-120 (1990).

47. Bharadwaj, M. et al. alphaV-class integrins exert dual roles on alpha5betal integrins to strengthen adhesion to fibronectin. Nat Commun 8, 14348, https://doi.org/10.1038/ncomms14348 (2017).

48. Pozzi, A., Wary, K. K., Giancotti, F. G. \& Gardner, H. A. Integrin alphalbetal mediates a unique collagen-dependent proliferation pathway in vivo. J Cell Biol 142, 587-594 (1998).

49. Popov, C. et al. Integrins alpha2beta1 and alpha1 1betal regulate the survival of mesenchymal stem cells on collagen I. Cell Death Dis 2, e186, https://doi.org/10.1038/cddis.2011.71 (2011).

50. Wary, K. K., Mainiero, F., Isakoff, S. J., Marcantonio, E. E. \& Giancotti, F. G. The adaptor protein Shc couples a class of integrins to the control of cell cycle progression. Cell 87, 733-743 (1996).

51. Barberis, L. et al. Distinct roles of the adaptor protein Shc and focal adhesion kinase in integrin signaling to ERK. J. Biol. Chem. 275, 36532-36540 (2000).

52. Xu, J., Zutter, M. M., Santoro, S. A. \& Clark, R. A. A three-dimensional collagen lattice activates NF-kappaB in human fibroblasts: role in integrin alpha2 gene expression and tissue remodeling. J Cell Biol 140, 709-719 (1998).

53. Klemke, R. L. et al. Regulation of cell motility by mitogen-activated protein kinase. J Cell Biol 137, 481-492 (1997).

54. Ronziere, M. C. et al. Integrin alphalbetal mediates collagen induction of MMP-13 expression in MC615 chondrocytes. Biochim Biophys Acta 1746, 55-64, https://doi.org/10.1016/j.bbamcr.2005.08.003 (2005). 
55. Kagami, S. et al. PDGF-BB enhances alphalbeta1 integrin-mediated activation of the ERK/AP-1 pathway involved in collagen matrix remodeling by rat mesangial cells. J Cell Physiol 198, 470-478, https://doi.org/10.1002/jcp.10433 (2004).

56. Wang, X. Q., Lindberg, F. P. \& Frazier, W. A. Integrin-associated protein stimulates alpha2beta1-dependent chemotaxis via Gimediated inhibition of adenylate cyclase and extracellular-regulated kinases. J Cell Biol 147, 389-400 (1999).

57. Chen, Y. et al. Thrombospondin 1 is a key mediator of transforming growth factor beta-mediated cell contractility in systemic sclerosis via a mitogen-activated protein kinase kinase (MEK)/extracellular signal-regulated kinase (ERK)-dependent mechanism. Fibrogenesis Tissue Repair 4, 9, https://doi.org/10.1186/1755-1536-4-9 (2011).

58. Weyts, F. A., Li, Y. S., van Leeuwen, J., Weinans, H. \& Chien, S. ERK activation and alpha v beta 3 integrin signaling through Shc recruitment in response to mechanical stimulation in human osteoblasts. J Cell Biochem 87, 85-92, https://doi.org/10.1002/ jcb.10278 (2002).

59. Barczyk, M. M. et al. A role for alpha1 lbetal integrin in the human periodontal ligament. J Dent Res $\mathbf{8 8}, 621-626$, https://doi. org/10.1177/0022034509339291 (2009).

60. Mustafa, K., Silva Lopez, B., Hultenby, K., Wennerberg, A. \& Arvidson, K. Attachment and proliferation of human oral fibroblasts to titanium surfaces blasted with $\mathrm{TiO} 2$ particles. A scanning electron microscopic and histomorphometric analysis. Clin Oral Implants Res 9, 195-207 (1998).

61. Zeltz, C. et al. alpha11betal Integrin is Induced in a Subset of Cancer-Associated Fibroblasts in Desmoplastic Tumor Stroma and Mediates In Vitro Cell Migration. Cancers (Basel) 11, https://doi.org/10.3390/cancers11060765 (2019).

62. Lu, N., Karlsen, T. V., Reed, R. K., Kusche-Gullberg, M. \& Gullberg, D. Fibroblast alphallbetal integrin regulates tensional homeostasis in fibroblast/A549 carcinoma heterospheroids. PLoS One 9, e103173, https://doi.org/10.1371/journal.pone.0103173 (2014).

63. Horzum, U., Ozdil, B. \& Pesen-Okvur, D. Step-by-step quantitative analysis of focal adhesions. MethodsX 1, 56-59, https://doi. org/10.1016/j.mex.2014.06.004 (2014).

64. Blacher, S. et al. Cell invasion in the spheroid sprouting assay: a spatial organisation analysis adaptable to cell behaviour. PLoS One 9, e97019, https://doi.org/10.1371/journal.pone.0097019 (2014).

\section{Acknowledgements}

The authors wish to thank Mona Grønning for excellent technical assistance and Brith Bergum at the Flow Cytometry Core Facility, University of Bergen, for helping with flow cytometry and cell sorting. The authors also wish to thank Prof. Kamal Mustafa for providing access to the TIRF microscope at the Tissue Engineering Group, Department of Clinical Dentistry, University of Bergen. P.E. was financed by a PhD scholarship from The Faculty of Medicine and Dentistry, University of Bergen. This project was supported by the Western Norway Regional Health Authority (ID 911899), Centre of Cancer Biomarkers (Centre of Excellence funded by Research council of Norway, Project No 223250), Norwegian-Polish EEA grant (ID 202952) and The Norwegian Centre for International Cooperation in Education (SIU) (PNA-2014/10057).

\section{Author contributions}

P.E. took part in experiment planning, performed majority of experiments, analyzed all the experiments, wrote the manuscript; J.A. contributed to cell proliferation and siRNA knockdown experiments; N.L. contributed to spheroid and siRNA knockdown experiments; C.Z. participated in experiment design and data interpretation; D.G. supervised, funded, designed the project, interpreted the data and wrote the manuscript.

\section{Competing interests}

Donald Gullberg is a named inventor on a patent filed by the University of Bergen for $\alpha 11$ monoclonal antibody mAb 210 F4 (PCT/ EP2019/051716).

\section{Additional information}

Supplementary information is available for this paper at https://doi.org/10.1038/s41598-019-51689-6.

Correspondence and requests for materials should be addressed to D.G.

Reprints and permissions information is available at www.nature.com/reprints.

Publisher's note Springer Nature remains neutral with regard to jurisdictional claims in published maps and institutional affiliations.

(c) (i) Open Access This article is licensed under a Creative Commons Attribution 4.0 International C. License, which permits use, sharing, adaptation, distribution and reproduction in any medium or format, as long as you give appropriate credit to the original author(s) and the source, provide a link to the Creative Commons license, and indicate if changes were made. The images or other third party material in this article are included in the article's Creative Commons license, unless indicated otherwise in a credit line to the material. If material is not included in the article's Creative Commons license and your intended use is not permitted by statutory regulation or exceeds the permitted use, you will need to obtain permission directly from the copyright holder. To view a copy of this license, visit http://creativecommons.org/licenses/by/4.0/.

(c) The Author(s) 2019 